Федотова В. А.

ДЕТЕРМИНАНТЫ ЖИЗНЕСТОЙКОСТИ У ТРЕХ ПОКОЛЕНИЙ СОВРЕМЕННОЙ РОССИИ

Российский психологичЕский жУРнАл, 2020, Т. 17, № 1, 74-91. doi: 10.21702/rpj.2020.1.6

СОЦИАЛЬНАЯ ПСИХОЛОГИЯ

УдК 159.9.072.43:316.6 doi: $10.21702 /$ rpj.2020.1.6

Оригинальная научная статья

\title{
Детерминанты жизнестойкости у трех поколений современной России
}

\author{
Вера А. Федотова \\ Национальный исследовательский университет «Высшая школа экономики» (НИУ ВШЭ - Пермь), \\ г. Пермь, Российская Федерация \\ E-mail: vera goldyreva@mail.ru \\ ORCID ID: http://orcid.org/0000-0003-2189-9791
}

\begin{abstract}
Аннотация
Ввеление. Актуальность и новизна исслеАования различий поколений связаны С неАостаточной разработанностью Аанной проблемы в рамках науки. В условиях современной Аействительности необходимо изучение фракторов, которые помогают человеку справляться со стрессогенными фракторами и нарастающей напряженностью. Цель исслеАования -в опрелелении преАикторов жизнестойкости у разного поколения россиян.

Методы. В эмпирическом исследовании была проведена Аиагностика ценностей, субъективного экономического благополучия и фракторов жизнестойкости россиян, проживающих в разных регионах Российской Фелерации, в возрасте от 18 Ао 75 ^ет. В холе исслеАования были использованы четыре метолики: метолика измерения инАивиАуальных ценностей PVQ-R, «Тест жизнестойкости» А. А. Аеонтьева, методика «Субъективное экономическое благополучие» В. А. Хащенко и тест смысложизненных ориентаций А. А. ^еонтьева.

Результаты. У представителей поколения Ү выше общий уровень жизнестойкости. На фоормирование жизнестойкости у всех трех рассмотренных поколений оказывает влияние значимость смысложизненной ориентации «локус контроля - жизны», но у поколений Х и Ү это влияние положительное, а у «беби-бумеров»-отрицательное. Негативное влияние на фрормирование жизнестойкости представителей поколения X, Y и «беби-бумеров» оказывает уровень экономической тревожности. У поколений Х и Ү на формирование жизнестойкости оказывает влияние значимость ценностей инАивиАуализма - Самостоятельность: мысли» и «Аостижение». ОбсужАение результатов. С ростом неАовольства своИм материальным положением, невозможностью откАаАЫвать Аеньги, с ростом экономической тревожности снижается уровень жизнестойкости россиян. Повышению уровня жизнестойкости у всех групп респонАентов может способствовать рост материального благополучия. Самостоятельность в выборе Аействий, наличие амбициозных целей в жизни, стремление быть успешным, необходимость чувствовать себя защищенным и в безопасности - повышают возможность че^овека противостоять стрессогенным фракторам у представителей поколений Х и Ү.
\end{abstract}

\section{КАючевые слова}

Жизнестойкость, инАивиАуальные ценности, смысложизненные ориентации, экономические установки, межпоколенные различия, поколение X, поколение Ү, беби-бумеры 
ФеДОтова В. А.

ДЕТЕРМИНАНТЫ ЖИЗНЕСТОЙКОСТИ У ТРЕХ ПОКОЛЕНИЙ СОВРЕМЕННОЙ РОССИИ

РосСИЙСКИй пСИХологИЧЕСКИй ЖУРнАл, 2020, Т. 17, № 1, 74-91. doi: 10.21702/rpj.2020.1.6

СОЦИАЛЬНАЯ ПСИХОЛОГИЯ

\section{Основные положения}

จ проблему различий поколений слеАует рассматривать с точки зрения базовых социально-психологических характеристик - жизнестойкости поколения, ценностей, смысложизненных ориентаций и экономических Установок;

$\checkmark$ умение справляться с жизненными трудностями зависит от ценностно-смысловых ориентиров и от УАовлетворенности своим материальным положением;

$\checkmark$ жизнестойкость вкАючает в себя вовлеченность, принятие риска и контроль;

$\checkmark$ молели жизнестойкости различны у трех поколений современной России.

\section{Для цитирования}

Федотова, В. А. (2020). Детерминанты жизнестойкости у трех поколений современной России. Российский психологический журнал, 17(1), 74-91. doi: 10.21702/rpj.2020.1.6

Дата получения рукописи: 02.10.2019

Дата окончания рецензирования: 18.01 .2020

Дата принятия к публикации: 21.01.2020

\section{Введение}

Актуальность темы обусловлена тем, что в условиях современной действительности необходимо изучение факторов, помогающих человеку справляться со стрессом и нарастающей напряженностью. В ранних исследованиях было выявлено, что чем выше жизнестойкость, тем быстрее происходит адаптация к новым жизненным условиям, меньше выражены культурный шок и субъективный уровень стресса (Ванакова, 2014; Кабанченко, 2017; Климов, 2011а, 20116, 2010; Постникова, 2016). Учитывая темп развития общества, нестабильность экономики и политических отношений, крайне важно выявить факторы и личностные характеристики, способствующие развитию жизнестойкости у разных поколений россиян. Стоит отметить, что данный психологический конструкт уже активно изучается на Западе как отдельный феномен и во взаимосвязи с другими психологическими категориями. В российской же действительности интерес к данной проблеме только начинает проявляться.

В широком смысле жизнестойкость служит отражением жизненной силы, которая позволяет человеку взаимодействовать со средой и способствует возникновению у него «субъективного чувства живости и энергии», детерминирующего, по мнению Р. Эммонса, субъективное чувство личного благополучия (Богомаз и Баланев, 2009). Как отмечает Д. А. Леонтьев, именно жизнестойкость позволяет человеку выносить неустранимую тревогу, сопровождающую выбор будущего (неизвестности), а не прошлого (неизменности) в ситуации экзистенциальной дилеммы (Кузьмина и Мороз, 2010; Леонтьев, 2011). Согласно взглядам С. Мадди, человек, обладающий жизнестойкостью, научается видеть в постоянных изменениях все новые и новые возможности и пути решения жизненных задач (Богомаз и Баланев, 2009; Kobasa, Maddi, \& Kahn, 1982).

Жизнестойкость, как черта личности, позволяющая преобразовывать стрессогенные жизненные события в новые возможности, связана со стремлением сохранять личностные ценности, входящие в ядро личности, а такой аспект жизнестойкости, как психологическая живучесть и расширенная эффективность, связан со способностью изменять менее устойчивые личностные ценности в зависимости от ситуации (Хромов, 2012). В 2010 г. проведено исследование, 
ФедОтова В. А.

ДЕТЕРМИНАНТЫ ЖИЗНЕСТОЙКОСТИ У ТРЕХ ПОКОЛЕНИЙ СОВРЕМЕННОЙ РОССИИ

Российский психологичЕский жУРнАл, 2020, Т. 17, № 1, 74-91. doi: 10.21702/rpj.2020.1.6

СОЦИАЛЬНАЯ ПСИХОЛОГИЯ

целью которого было изучение связи между жизнестойкостью и фрустрацией (Кузьмина и Мороз, 2010). Авторы подтвердили гипотезу, что для людей с высоким уровнем жизнестойкости характерен поиск конструктивного выхода из ситуации фрустрации, а также выявили следующие закономерности:

1. Для людей с высоким уровнем жизнестойкости характерен импунитивный тип выхода из ситуации фрустрации.

2. Чем выше уровень жизнестойкости, тем выше уровень социальной адаптации.

Кроме этого, была эмпирически установлена связь между параметрами жизнестойкости и самооценки. Это говорит о том, что чем больше уверен в себе человек, тем, соответственно, выше его жизнестойкость. Анализ взаимосвязи жизнестойкости и коммуникативных навыков выявил следующие закономерности: существует положительная взаимосвязь между жизнестойкостью и компетентной коммуникацией, а также обратные взаимосвязи между жизнестойкостью и агрессивным способом коммуникации, жизнестойкостью и защитным способом коммуникации. Это означает то, что жизнестойкому человеку в социуме в ситуации коммуникации присуще компетентное поведение и не присуще агрессивное и защитное.

Также были исследованы взаимосвязи между жизнестойкостью и саморегуляцией человека. Найденные прямые значимые взаимосвязи свидетельствуют о том, что чем больше развита жизнестойкость, тем выше уровень саморегуляции, т.е. человек проявляет самостоятельность, гибко и адекватно реагирует на изменение внешних условий. Анализ взаимосвязей между смысложизненными ориентациями и жизнестойкостью показал значимые прямые корреляции - это говорит о том, что наличие жизнестойкости отмечается также достаточно высоким уровнем осмысленности, результативности, эмоциональной насыщенности жизни человека (Хромов, 2012).

Несмотря на наличие ряда работ о взаимосвязи жизнестойкости с разными психологическими конструктами, на данный момент отсутствуют работы, изучающие факторы, формирующие жизнестойкость, тем более в межпоколенном аспекте. Стоит отметить, что события последних лет (экономический кризис, террористические угрозы, техногенные катастрофы, нестабильные политические отношения и т.д.) являются сильным фактором, оказывающим давление на личность. Проживание этих событий привело к тому, что в настоящее время отмечается общее снижение чувства безопасности и защищенности человека. Перед наукой стоит задача осмысления психологических характеристик и предпосылок, которые обусловливают успешную адаптацию человека в стремительно меняющемся мире. Умение справляться с жизненными трудностями зависит от личностного потенциала, от степени личностной зрелости, от субъективного экономического благополучия и от ценностно-смысловых ориентиров. Таким образом, цель представленного исследования заключается в выявлении предикторов жизнестойкости у разного поколения россиян. В качестве детерминант выступают индивидуальные ценности, смысложизненные ориентации и факторы субъективного экономического благополучия.

\section{Типология поколений в современной науке}

Представители каждого поколения - люди, объединенные по определенному возрастному диапазону и значимым жизненным событиям, которые они пережили на своем критическом этапе развития, или, другими словами, в возрасте формирования личности (Хомякова, 2011; Шамис и Антипов, н. д.; Haeberle, Herzber, \& Hobbs, 2009; Macky, Gardner, \& Forsyth, 2008; 
ФеДОтова В. А.

ДЕТЕРМИНАНТЫ ЖИЗНЕСТОЙКОСТИ У ТРЕХ ПОКОЛЕНИЙ СОВРЕМЕННОЙ РОССИИ

РосСИЙСКИй пСИХологИЧЕСКИй ЖУРнАл, 2020, Т. 17, № 1, 74-91. doi: 10.21702/rpj.2020.1.6

СОЦИАЛЬНАЯ ПСИХОЛОГИЯ

Mannheim, 1952; Rudolph, Rauvola, \& Zacher, 2018; Yusoff \& Kian, 2013). Представители поколений схожи своей историей, особым типом личности и поведением, сформированным этой историей (Murphy, Gibson, \& Greenwood, 2010; Ozkan \& Solmaz, 2015; Yang \& Guy, 2006).

В современных научных работах в большинстве случаев поколение рассматривается с точки зрения теории У. Штрауса и Н. Хоува (Асташова, 2014; Strauss \& Howe, 1991), которая объединяет в себе основные подходы социологии, социальной психологии и психологии развития. С точки зрения данного подхода, временные рамки поколения определяются категорией ценностей, а не просто датой рождения.

\section{Различия поколений современной России}

Поколение Y - индивидуалисты, которые хотят выделиться как личности и нацелены на достижение собственных целей. Они ориентированы на себя чуть меньше, чем поколение Z (Арцимович, 2017; Ozkan \& Solmaz, 2015). Они открыты к изменениям, готовы идти на риск, обладают гибким мышлением, тем не менее, подвержены влиянию бренда и моды (Волкова и Чикер, 2016; Гурова и Евдокимова, 2016). Как и представители поколения $\mathrm{X}$, ценят баланс между работой и личной жизнью, но, в то же время, для них важен насыщенный досуг (Anderson, Baur, Griffith, \& Buckley, 2017; Wong, Wan, \& Gao, 2017; Yusoff \& Kian, 2013).

Представители поколения X так же, как представители поколения Y, готовы к переменам, готовы идти на риск ради достижения цели, являются ярко выраженными индивидуалистами (Волкова и Чикер, 2016; Гурова и Евдокимова, 2016; Yusoff \& Kian, 2013). Для них значима ценность семьи, поэтому они не готовы жертвовать своими часами досуга (Williams, Page, Petrosky, \& Hernandez, 2010; Yusoff \& Kian, 2013).

Для поколения «беби-бумеров» характерны такие черты, как коллективизм, оптимизм и независимость; они ценят традиции и благожелательно настроены по отношению к другим людям. Они выросли в эпоху процветания и оптимистических взглядов и поддерживались чувством, что они являются особым поколением, которое способно изменить мир (Yusoff \& Kian, 2013). Кроме этого, для поколения «беби-бумеров» характерны культ молодости и здоровья и религиозность (Черников, 2014; Волкова и Чикер, 2016).

\section{Методы}

Цель исследования - определить факторы, оказывающие наибольшее влияние на формирование жизнестойкости у разных поколений россиян. Предмет исследования - ценности, смысложизненные ориентации, субъективное экономическое благополучие как предикторы жизнестойкости у разных поколений россиян. В качестве методического инструментария в данном исследовании выступили следующие методики:

1. Методика «Субъективное экономическое благополучие» (Постникова, 2016; Хащенко, 2005, 2011). Методика представляет собой опросник, состоящий из 26 утверждений, к каждому из которых предлагается пять вариантов ответов, где 1 соответствует ответу «не согласен с утверждением», а 5 - «полностью согласен». Далее, в соответствии с ключом, подсчитываются показатели по таким факторам, как: оптимизм/пессимизм, экономическая тревожность, субъективная адекватность дохода, финансовая депривированность, текущее благосостояние семьи. Данный опросник был выбран нами, поскольку он предоставляет широкие возможности в анализе богатого и разнопланового эмпирического опыта в области изучения 
Федотова В. А.

ДЕТЕРМИНАНТЫ ЖИЗНЕСТОЙКОСТИ У ТРЕХ ПОКОЛЕНИЙ СОВРЕМЕННОЙ РОССИИ

Российский психологичЕский жУРнАл, 2020, Т. 17, № 1, 74-91. doi: 10.21702/rpj.2020.1.6

СОЦИАЛЬНАЯ ПСИХОЛОГИЯ

взаимоотношений, объективных условий жизни и благополучия человека, «экономики» благополучия и счастья, субъективных индикаторов благосостояния, ценностно-смысловых аспектов материальных достижений. Опросник СЭБ дает возможность изучения фундаментальной проблемы соотношения объективных и субъективных оценок экономических условий жизни на основе новой методологии.

2. «Tест жизнестойкости» (Кузьмина и Мороз, 2010; Леонтьев и Рассказова, 2006) представляет собой адаптацию Д. А. Леонтьевым опросника Hardiness Survey, разработанного американским психологом С. Мадди (Anderson et al., 2017). Данная методика представляет собой опросник, состоящий из 45 утверждений, к каждому из которых предлагается четыре варианта ответов, где 1 соответствует ответу «не согласен с утверждением», а 4 - «полностью согласен». Далее, в соответствии с ключом, подсчитываются показатели по таким факторам, как вовлеченность, контроль и принятие риска.

3. Методика измерения индивидуальных ценностей PVQ-R (Хомякова, 2011; Шварц, Бутенко, Седова и Липатова, 2012). Теория базовых ценностей Ш. Шварца в последние несколько лет послужила основой сотен исследований. Первоначально в них проверялась связь 10 (власть, достижение, гедонизм, стимуляция, самостоятельность, универсализм, заботливость, традиции, конформизм, безопасность) базовых ценностей по Ш. Шварцу или четырех метаценностей с различными установками, представлениями, мнениями, типами поведения, качествами личности и т.д. В 2011 г. Ш. Шварцем была создана новая методика, в которую входили уже не 10 ценностей, а 19. Уточненная теория совместима с первоначальной структурой из десяти более широких конструктов, т. к. эти 19 ценностей охватывают тот же мотивационный континуум, что и изначальные десять. Для исследования был принят формат опросника $P V Q$, где каждый из пунктов был ограничен одним предложением. Пункты описывают цели личности, устремления или желания, которые неявно указывают на важность той или иной ценности. Ценности респондентов выводятся из имплицитных ценностей людей, которых они считают похожими на себя. Шкала ответов содержит 6 альтернатив: 0 - совсем не похож на меня, 1 - не похож на меня, 2 - мало похож на меня, 3 - немного похож на меня, 4 - похож на меня, 5 - очень похож на меня. Ш. Шварц с соавторами в статье «Уточненная теория базовых индивидуальных ценностей: применение в России» представили подтверждения уточненной теории. Данные были получены при опросе 15 выборок студентов ( $\mathrm{N}=3909)$ и взрослых (N = 2150) в Финляндии, Германии, Израиле, Италии, Новой Зеландии, Польше, Португалии, Швейцарии, Турции и США.

4. «Tест смысложизненных ориентаций (СЖО)» (Климов, 2010; Леонтьев, 2011). Методика представляет собой опросник, состоящий из 20 пар противоположных утверждений. Задача респондента - выбрать одно из двух утверждений, которое больше соответствует действительности, и отметить одну из цифр 1, 2, 3, в зависимости от того, насколько он уверен в выборе (или «0», если оба утверждения одинаково верны). Далее, в соответствии с ключом, подсчитываются показатели по пяти шкалам: цели в жизни, процесс жизни, результативность жизни, локус контроля -Я и локус контроля -жизнь.

\section{Респонденты}

Сбор данных осуществлялся в период с 2018 по 2019 гг. Всего было 621 человек - представителей поколения Ү (годы рождения 1984-2000); 418 представителей поколений X (1963-1984) и 291 респондента 1943-1963 годов рождения, так называемых «беби-бумеров». В качестве 
ФЕДОтова В. А.

ДЕТЕРМИНАНТЫ ЖИЗНЕСТОЙКОСТИ У ТРЕХ ПОКОЛЕНИЙ СОВРЕМЕННОЙ РОССИИ

РОССИЙСКИЙ ПСИХОЛОГИЧЕСКИЙ ЖХРнАл, 2020, Т. 17, № 1, 74-91. doi: 10.21702/rpj.2020.1.6

СОЦИАЛЬНАЯ ПСИХОЛОГИЯ

основы классификации поколений нами был выбран подход социологов Ю. А. Левады, В. В. Гаврилюка, Н. А. Трикозы и психологов Е. М. Шамис и А. Антипова (Арцимович, 2017; Шамис и Антипов, н.д.).

\section{Результаты}

Результаты исследования жизнестойкости

Описательные статистики и межпоколенные различия в факторах жизнестойкости по критерию Краскела -Уоллиса приведены в таблице 1.

\begin{tabular}{|c|c|c|c|c|c|c|}
\hline $\begin{array}{l}\text { Таблица } 1 \\
\text { Межпоколенны }\end{array}$ & ичия в орак & орах жизнест & ойкости: п & критерию Кр & acкела-у & омиса \\
\hline Шкa^a & $\begin{array}{r}\text { ПреАC } \\
\text { поко }\end{array}$ & $\frac{\text { авители }}{\text { ения } Y}$ & $\begin{array}{r}\text { ПредC } \\
\text { поко }\end{array}$ & $\begin{array}{l}\text { авители } \\
\text { ения X }\end{array}$ & $\begin{array}{r}\text { ПреАC } \\
\frac{\text { поколе }}{\underline{\sigma y}}\end{array}$ & $\begin{array}{l}\text { авители } \\
\text { ия «беби- } \\
\text { еров» }\end{array}$ \\
\hline & Ср. знач. & СтанА. ОткА. & Ср. знач. & СтанА. ОтКА. & Ср. знач. & СтанА. ОтКА \\
\hline Вовлеченность & $33,7^{*}$ & 0,99 & $29,1^{*}$ & 0,63 & $31,4^{*}$ & 0,95 \\
\hline Контроль & 27,9 & 1,24 & 26,4 & 1,12 & 23,3 & 1,05 \\
\hline Принятие риска & $11,4^{* *}$ & 0,86 & $12,8^{* *}$ & 0,08 & $9,7^{* *}$ & 0,52 \\
\hline $\begin{array}{l}\text { Общий уровень } \\
\text { жизнестойкости }\end{array}$ & 73,0 & 0,94 & 68,3 & 0,88 & 64,4 & 0,73 \\
\hline
\end{tabular}

Значимые различия были выявлены между поколениями по двум составляющим жизнестойкости. Факторы жизнестойкости «вовлеченность» и «принятие риска» выше у представителей поколения Ү. Молодые россияне с развитым компонентом вовлеченности получают удовольствие от собственной деятельности, они постоянно заняты, стараются быть в курсе всего происходящего, любят знакомиться с новыми людьми, и им всегда есть, чем заняться. Принятие риска выше у россиян в возрасте от 35 до 55 лет. Представителей поколения X раздражают события, из-за которых они вынуждены менять свой распорядок дня; они считают, что «лучше синица в руках, чем журавль в небе»; живут полной жизнью; практически всегда могут повлиять на результат того, что происходит вокруг.

Общий уровень жизнестойкости выше у представителей поколения Ү, россиян в возрасте от 19 до 34 лет. Молодые респонденты уверены в своих решениях, им нравится быть постоянно 
ФедОтова В. А.

ДЕТЕРМИНАНТЫ ЖИЗНЕСТОЙКОСТИ У ТРЕХ ПОКОЛЕНИЙ СОВРЕМЕННОЙ РОССИИ

Российский психологический жУРнАл, 2020, Т. 17, № 1, 74-91. doi: 10.21702/rpj.2020.1.6

СОЦИАЛЬНАЯ ПСИХОЛОГИЯ

занятыми, они предпочитают ставить перед собой труднодостижимые цели и добиваться их, им легко сближаться с новыми людьми, неожиданности дарят интерес к жизни, и их собственная жизнь кажется им осмысленной и интересной.

\section{Детерминанты жизнестойкости у представителей разных поколений россиян}

На основе проведенного множественного регрессионного анализа были выявлены факторы, оказывающие влияние на формирование жизнестойкости у разных поколений россиян. Ниже представлена модель жизнестойкости, и факторы (ценности, экономические установки, смысложизненные ориентации), влияющие на жизнестойкость у представителей поколения Y (см. табл. 2, 3, 4).

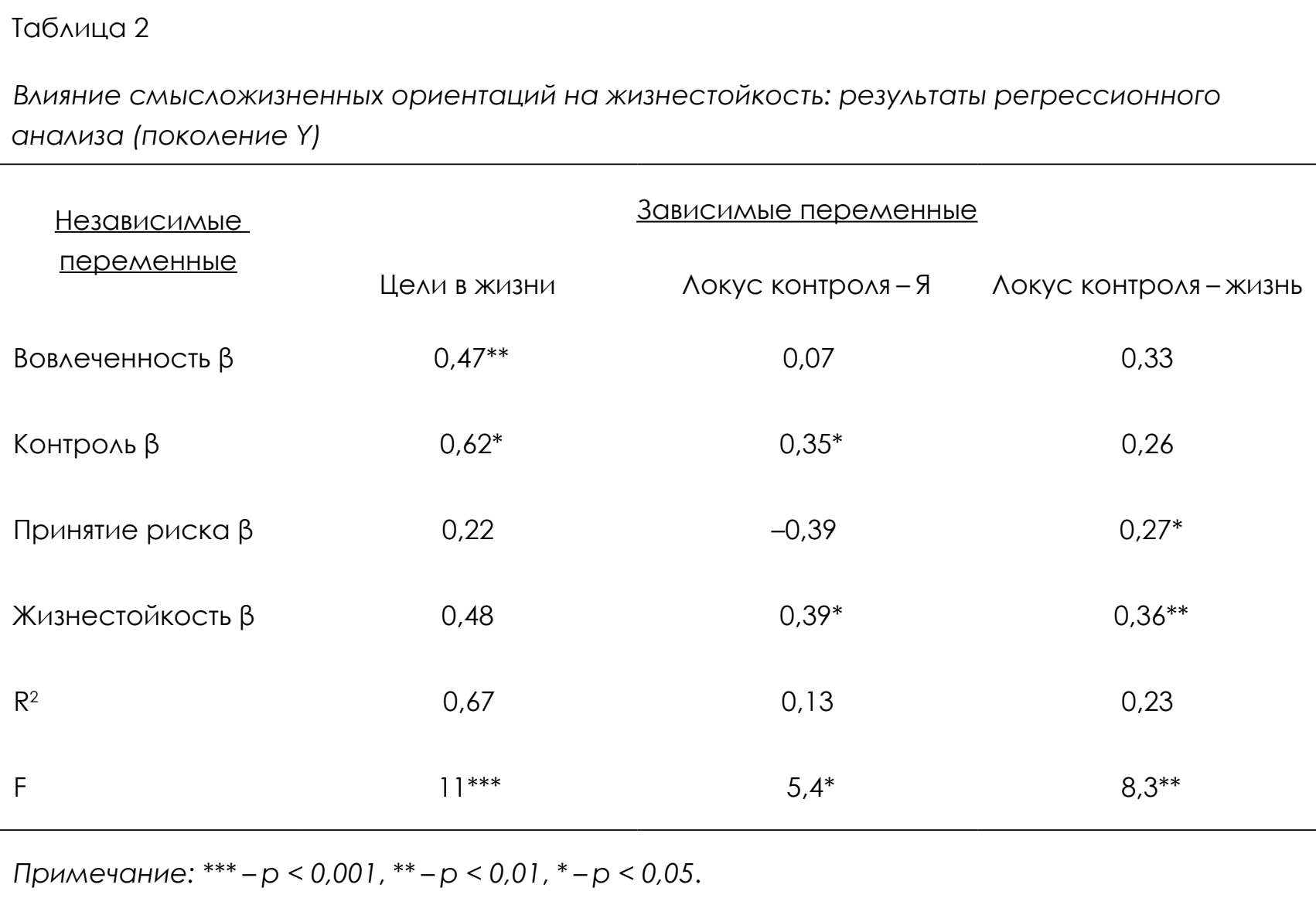

На формирование жизнестойкости у представителей поколения Ү влияют такие смысложизненные ориентации, как «локус контроля - Я» и «локус контроля-жизнь». Свобода выбора, возможность строить жизнь в соответствии со своими целями и задачами, управляемость жизни и установки на то, что человеку дано контролировать свою жизнь, свободно принимать решения и воплощать их в жизнь, влияют на способность личности выдерживать стрессовую ситуацию, сохраняя внутреннюю сбалансированность. 
ФЕДОтова В. А.

ДЕТЕРМИНАНТЫ ЖИЗНЕСТОЙКОСТИ У ТРЕХ ПОКОЛЕНИЙ СОВРЕМЕННОЙ РОССИИ

РОССИЙСКИЙ ПСИХОЛОГИЧЕСКИЙ ЖХРнАл, 2020, Т. 17, № 1, 74-91. doi: 10.21702/rpj.2020.1.6

СОЦИАЛЬНАЯ ПСИХОЛОГИЯ

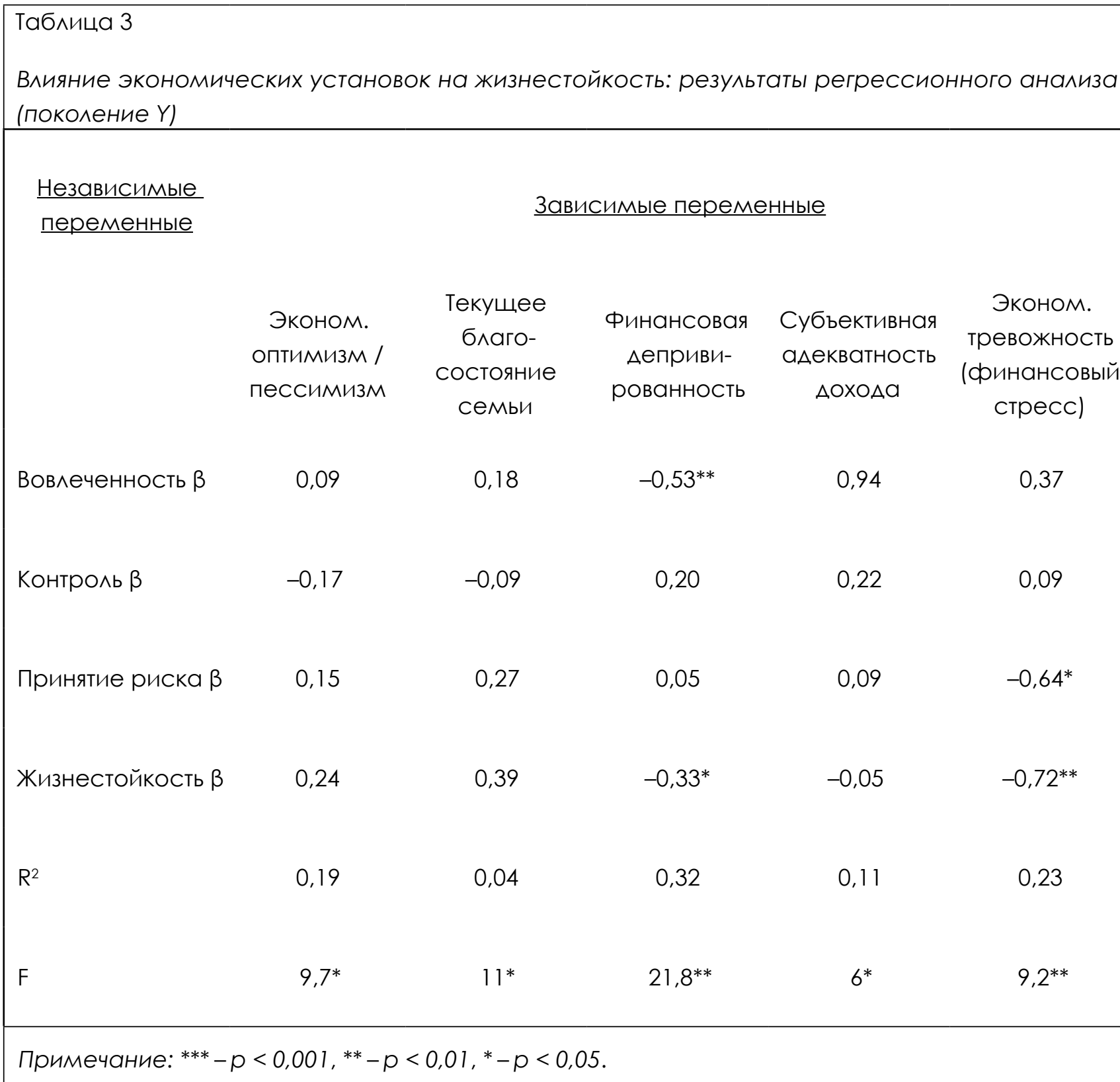

В ходе анализа данных были установлены отрицательные регрессионные связи с экономическими установками: финансовой депривированностью и финансовым стрессом. Жизнестойкость молодых россиян возрастает при снижении финансовой депривированности и уровня финансового стресса. Недостаток денежных средств, беспокойство за материальное положение в будущем, ситуация, когда денежные средства не удовлетворяют основным потребностям, негативным образом сказываются на жизнестойкости молодых россиян в возрасте от 18 до 34 лет. 
ФедОтова В. А.

ДЕТЕРМИНАНТЫ ЖИЗНЕСТОЙКОСТИ У ТРЕХ ПОКОЛЕНИЙ СОВРЕМЕННОЙ РОССИИ

Российский психологический жУРнАл, 2020, Т. 17, № 1, 74-91. doi: 10.21702/rpj.2020.1.6

СОЦИАЛЬНАЯ ПСИХОЛОГИЯ

Таблица 4
Влияние ценностей на жизнестойкость (поколение Y): результаты регрессионного анализа

Независимые

переменные

Зависимые переменные

CaMo-

стоятельность ГеАОНизм

Аостижение

B^асть:

MысАИ

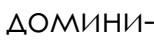

рование

Безопасность:

Аичная

Вовлеченность $\beta$

0,21

$0,62 *$

0,09

0,25

0,63

Контроль $\beta$

$0,71^{* *}$

0,17

0,23

$0,60 * *$

$-0,57$

Принятие риска $\beta$

$0,55^{*}$

0,23

0,37

0,38

$-0,22 *$

Жизнестойкость $\beta$

$0,34 *$

0,47

$0,25^{*}$

$0,78^{* *}$

0,05

$\mathrm{R}^{2}$

0,42

0,13

0,12

0,31

0,15

F

$13,07^{* *}$

$5,5^{*}$

$6,7^{*}$

$25^{* *}$

$7,4^{* *}$

Примечание: ${ }^{* *}-p<0,001,{ }^{* *}-p<0,01,{ }^{*}-p<0,05$.

Регрессионный анализ, направленный на выявление влияния индивидуальных ценностей на жизнестойкость, позволил сделать вывод, что самостоятельность в принятии решений, планировании деятельности независимо от других людей и внешних обстоятельств, свобода выбора, наличие амбициозных целей в жизни, стремление быть успешным и властным,-влияют на жизнестойкость молодых россиян.

Далее представлены факторы жизнестойкости представителей поколения X (табл. 5, 6, 7). 
ФЕДОтова В. А.

ДЕТЕРМИНАНТЫ ЖИЗНЕСТОЙКОСТИ У ТРЕХ ПОКОЛЕНИЙ СОВРЕМЕННОЙ РОССИИ

РОССИЙСКИЙ ПСИХОЛОГИЧЕСКИЙ ЖХРнАл, 2020, Т. 17, № 1, 74-91. doi: 10.21702/rpj.2020.1.6

СОЦИАЛЬНАЯ ПСИХОЛОГИЯ

\begin{tabular}{|c|c|c|c|c|c|c|}
\hline \multirow{2}{*}{$\frac{\text { Независимые }}{\underline{\text { переменные }}}$} & \multicolumn{6}{|c|}{ Зависимые переменные } \\
\hline & $\begin{array}{l}\text { Само- } \\
\text { стоятель- } \\
\text { ность: } \\
\text { поступки }\end{array}$ & $\begin{array}{c}\text { Само- } \\
\text { стоятельность: } \\
\text { мысли }\end{array}$ & $\begin{array}{l}\text { Аости- } \\
\text { жение }\end{array}$ & $\begin{array}{l}\text { Репу- } \\
\text { тация }\end{array}$ & $\begin{array}{c}\text { Безопас- } \\
\text { ность: } \\
\text { мичная }\end{array}$ & $\begin{array}{l}\text { Б^агожелатель- } \\
\text { ность: забота }\end{array}$ \\
\hline Вовлеченность $\beta$ & 0,08 & 0,27 & 0,70 & 0,28 & 0,06 & 0,13 \\
\hline Контроль $\beta$ & 0,24 & $0,39 *$ & 0,05 & 0,12 & 0,18 & $0,76^{* *}$ \\
\hline Принятие риска $\beta$ & $0,68^{* *}$ & 0,56 & 0,12 & $-0,33^{*}$ & 0,21 & 0,35 \\
\hline Жизнестойкость $\beta$ & $0,21^{*}$ & 0,18 & $0,24^{*}$ & 0,23 & $0,87^{* *}$ & 0,24 \\
\hline $\mathrm{R}^{2}$ & 0,5 & 0,13 & 0,12 & 0,09 & 0,15 & 0,9 \\
\hline $\mathrm{F}$ & $16^{* *}$ & $5,5^{*}$ & $6,7^{*}$ & $8^{*}$ & $7,4^{* *}$ & $15,7^{* *}$ \\
\hline
\end{tabular}

Самостоятельность в выборе действий, наличие амбициозных целей в жизни, стремление быть успешным, необходимость чувствовать себя защищенным и в безопасности - повышают возможность человека противостоять стрессогенным факторам. 
ФедОтова В. А.

ДЕТЕРМИНАНТЫ ЖИЗНЕСТОЙКОСТИ У ТРЕХ ПОКОЛЕНИЙ СОВРЕМЕННОЙ РОССИИ

Российский психологический жУРнАл, 2020, Т. 17, № 1, 74-91. doi: 10.21702/rpj.2020.1.6

СОЦИАЛЬНАЯ ПСИХОЛОГИЯ

\begin{tabular}{|c|c|c|c|c|c|}
\hline \multicolumn{6}{|c|}{$\begin{array}{l}\text { Таблица } 6 \\
\text { Влияние смысложизненных ориентаций на жизнестойкость: результаты регрессионного анализа } \\
\text { (поколение Х) }\end{array}$} \\
\hline \multirow{2}{*}{$\begin{array}{l}\text { Независимые } \\
\underline{\text { переменные }}\end{array}$} & \multicolumn{5}{|c|}{ Зависимые переменные } \\
\hline & Цели в жизни & $\begin{array}{c}\text { Процесс } \\
\text { жизни }\end{array}$ & $\begin{array}{c}\text { Результа- } \\
\text { тивность } \\
\text { жизни }\end{array}$ & $\begin{array}{c}\text { ^окус } \\
\text { контроля - }\end{array}$ & $\begin{array}{c}\text { ^окус } \\
\text { контроля- } \\
\text { жизнь }\end{array}$ \\
\hline Вовлеченность $\beta$ & $0,39 *$ & 0,38 & 0,29 & 0,33 & 0,48 \\
\hline Контроль $\beta$ & 0,13 & $0,43^{*}$ & $0,76^{* *}$ & 0,78 & 0,09 \\
\hline Принятие риска $\beta$ & 0,46 & 0,17 & 0,05 & 0,05 & 0,74 \\
\hline Жизнестойкость $\beta$ & $0,58^{* *}$ & $-0,25$ & 0,17 & 0,45 & $0,44^{*}$ \\
\hline $\mathrm{R}^{2}$ & 0,31 & 0,11 & 0,17 & 0,14 & 0,39 \\
\hline $\mathrm{F}$ & $10^{* *}$ & $7,8^{* *}$ & $8,4^{* *}$ & $7,2^{*}$ & $6^{*}$ \\
\hline
\end{tabular}

У представителей поколения X-россиян в возрасте от 35 до 55 лет - на формирование жизнестойкости оказывают влияние смысложизненные ориентации «локус контроля - жизнь» (положительное влияние) и фактор субъективно-экономического благополучия - финансовый стресс (отрицательное влияние) (как и у представителей поколения Ү). Кроме этого, смысложизненная ориентация «цели в жизни» повышает уровень жизнестойкости респондентов. Наличие целей в жизни и представления о себе как о сильной личности, обладающей достаточной свободой выбора, чтобы построить свою жизнь в соответствии со своими целями и задачами и представлениями о ее смысле, влияют на жизнестойкость представителей поколения $X$, на умение справляться со стрессовыми ситуациями и формировать адаптационные защитные механизмы. 
ФЕДОтова В. А.

ДЕТЕРМИНАНТЫ ЖИЗНЕСТОЙКОСТИ У ТРЕХ ПОКОЛЕНИЙ СОВРЕМЕННОЙ РОССИИ

РОССИЙСКИЙ ПСИХОЛОГИЧЕСКИЙ ЖХРнАл, 2020, Т. 17, № 1, 74-91. doi: 10.21702/rpj.2020.1.6

СОЦИАЛЬНАЯ ПСИХОЛОГИЯ

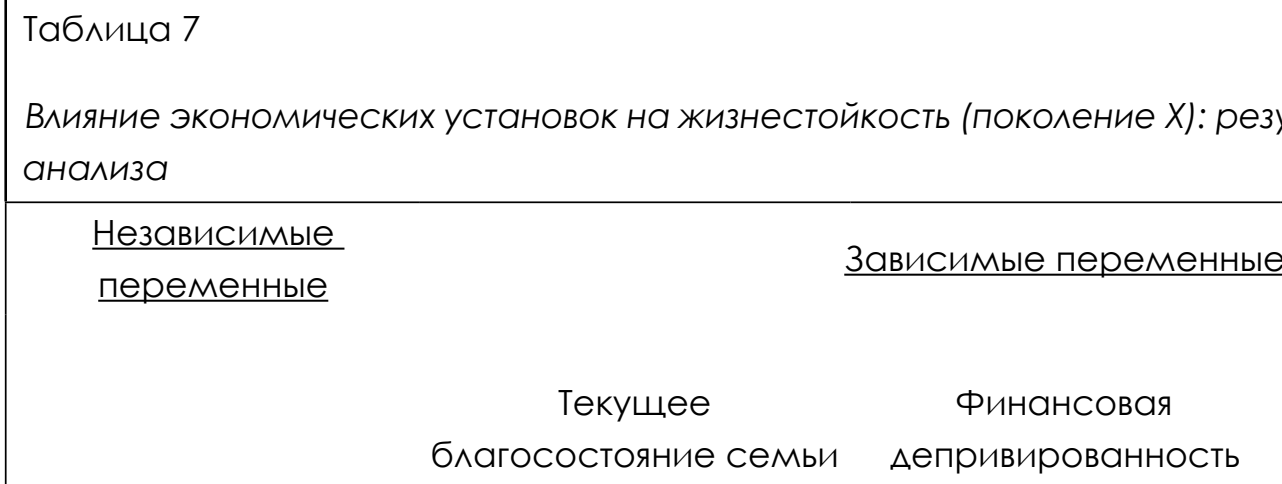

Экономическая

тревожность

(фринансовый стресс)
Вовлеченность $\beta$

Контроль $\beta$

Принятие риска $\beta$

Жизнестойкость $\beta$

$\mathrm{R}^{2}$

F
$-0,34^{*}$

0,57

$-0,37^{* *}$

0,18

0,12

$6,7^{*}$
0,08

0,22

0,14

$-0,59 * *$

0,13

$5,5^{*}$

$7,4^{* *}$

Примечание: ${ }^{* *}-p<0,001,{ }^{* *}-p<0,01,{ }^{*}-p<0,05$.

Высокий уровень финансовой депривированности и экономической тревожности снижает уровень жизнестойкости у россиян поколения $\mathrm{X}$, а точнее, оказывает негативное влияние на факторы жизнестойкости «вовлеченность» и «принятие риска». 
ФедОтова В. А.

ДЕТЕРМИНАНТЫ ЖИЗНЕСТОЙКОСТИ У ТРЕХ ПОКОЛЕНИЙ СОВРЕМЕННОЙ РОССИИ

Российский психологический жУРнАл, 2020, Т. 17, № 1, 74-91. doi: 10.21702/rpj.2020.1.6

СОЦИАЛЬНАЯ ПСИХОЛОГИЯ

Факторы жизнестойкости у представителей поколения беби-бумеров

\begin{tabular}{|c|c|c|c|c|c|}
\hline $\begin{array}{l}\text { Таблица } 8 \\
\text { Влияние смысложиз } \\
\text { (поколение «беби- }\end{array}$ & $\begin{array}{l}\text { ных ориентаци } \\
\text { еров») }\end{array}$ & на жизнест & ость: резуль & ты регрессио & ного анализс \\
\hline$\frac{\text { Независимые }}{\text { переменные }}$ & & $\underline{3 a B}$ & мые перел & нные & \\
\hline & Цели в жизни & $\begin{array}{l}\text { Процесс } \\
\text { жизни }\end{array}$ & $\begin{array}{l}\text { Результа- } \\
\text { тивность } \\
\text { жизни }\end{array}$ & $\begin{array}{c}\text { ^окус } \\
\text { Контроля-Я }\end{array}$ & $\begin{array}{c}\text { ^окус } \\
\text { контроля- } \\
\text { жизнь }\end{array}$ \\
\hline Вовлеченность $\beta$ & 0,07 & $0,22^{*}$ & 0,28 & 0,19 & 0,08 \\
\hline Контроль $\beta$ & 0,46 & 0,05 & $0,49 *$ & 0,48 & 0,29 \\
\hline Принятие риска $\beta$ & 0,09 & 0,48 & $-0,33$ & $0,87^{* *}$ & 0,18 \\
\hline Жизнестойкость $\beta$ & 0,35 & 0,46 & $0,38^{* *}$ & $0,62^{*}$ & $-0,55^{*}$ \\
\hline$R^{2}$ & 0,04 & 0,13 & 0,14 & 0,24 & 0,31 \\
\hline $\mathrm{F}$ & 9,3 & $17,9^{*}$ & $8,9^{* *}$ & $15,9^{* *}$ & $12,04^{*}$ \\
\hline
\end{tabular}

Эмоционально насыщенная, наполненная смыслом жизнь и свобода выбора в стремлении выстраивать жизненную траекторию в соответствии со своими ценностями и установками положительно влияют на формирование жизнестойкости. В то же время низкий балл по ценностно-смысловой ориентации «локус контроля-жизнь», или, другими словами, неверие в свои силы контролировать события собственной жизни, негативно сказывается на жизнестойкости. 
ФЕДОтова В. А.

ДЕТЕРМИНАНТЫ ЖИЗНЕСТОЙКОСТИ У ТРЕХ ПОКОЛЕНИЙ СОВРЕМЕННОЙ РОССИИ

РОССИЙСКИЙ ПСИХОЛОГИЧЕСКИЙ ЖУРНАЛ, 2020, Т. 17, № 1, 74-91. doi: 10.21702/rpj.2020.1.6

СОЦИАЛЬНАЯ ПСИХОЛОГИЯ

Таблица 9
$\begin{aligned} & \text { Влияние экономических установок на жизнестойкость: результаты регр } \\ & \text { (поколение беби-бумеров) }\end{aligned}$
$\begin{array}{ll}\text { Независимые } \\ \text { переменные }\end{array}$

Экономический оптимизм / пессимизм

Финансовая Аепривированность
Экономическая

тревожность

(фринансовый стресс)
0,05

0,12

0,17

$-0,34^{*}$

0,41

$12,08^{*}$
Вовлеченность $\beta$

Контроль $\beta$

Принятие риска $\beta$
$-0,82^{* * *}$

Жизнестойкость $\beta$
0,04

$-0,28$

$-0,04$
$-0,71^{* *}$

$16,3^{*}$
$-0,25$

0,38

0,60

$-0,52^{* *}$

0,16

$21,4^{* *}$

Примечание: ${ }^{* * *}-p<0,001,{ }^{* *}-p<0,01,{ }^{*}-p<0,05$.

Экономический пессимизм и финансовая депривированность негативным образом влияют на формирование жизнестойкости у представителей поколения беби-бумеров. Рост благополучия ведет к росту жизнестойкости. 
ФедОтова В. А.

ДЕТЕРМИНАНТЫ ЖИЗНЕСТОЙКОСТИ У ТРЕХ ПОКОЛЕНИЙ СОВРЕМЕННОЙ РОССИИ

Российский психологический жУРнАл, 2020, Т. 17, № 1, 74-91. doi: 10.21702/rpj.2020.1.6

СОЦИАЛЬНАЯ ПСИХОЛОГИЯ

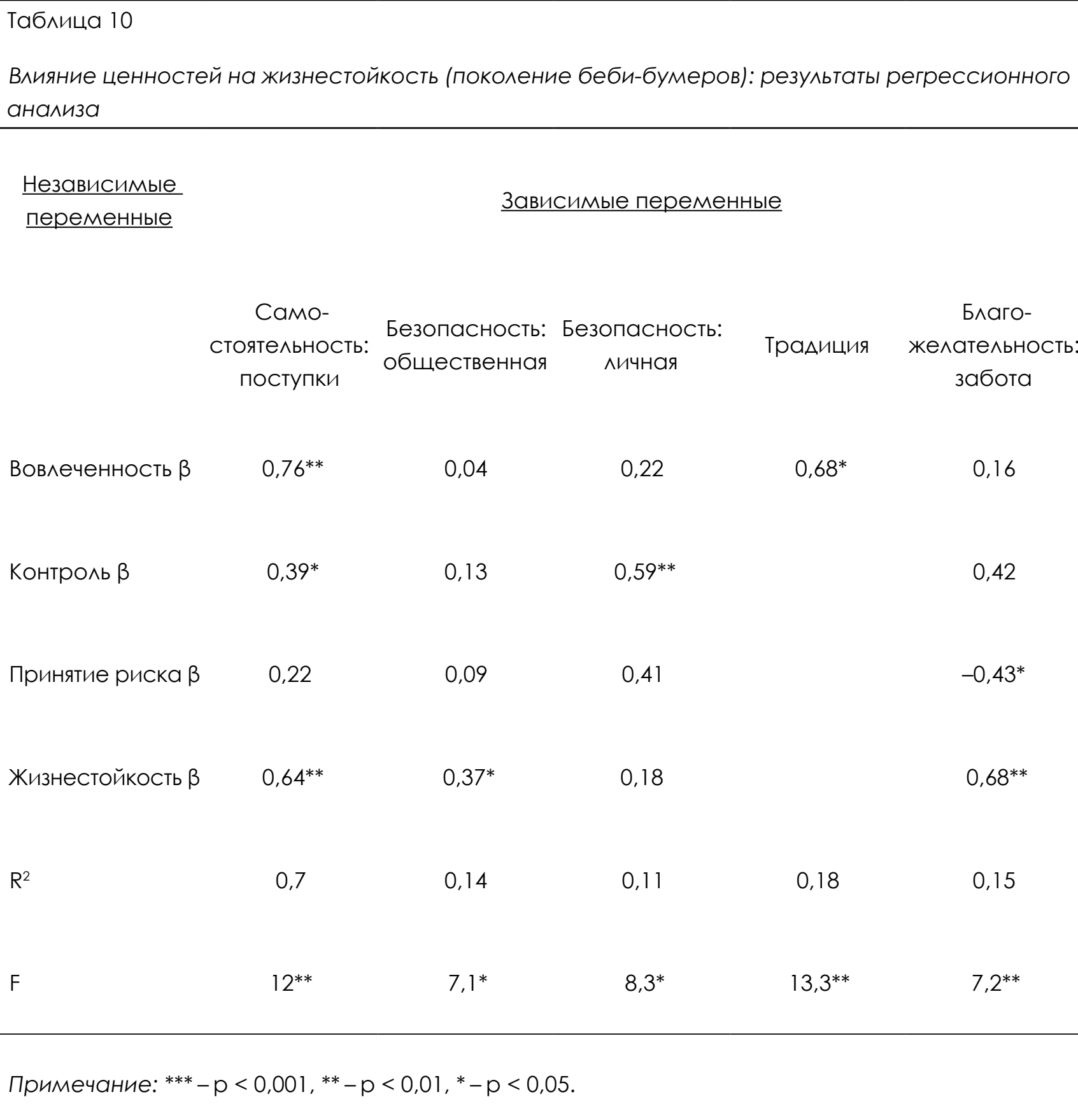

Порядок в обществе, уверенность в том, что страна сильная и может защитить своих граждан, стремление заботиться о своих близких, помогать дорогим людям, самостоятельность в выборе поступков и действий - повышают жизнестойкость респондентов в возрасте от 56 до 75 лет. 
ФеДОтова В. А.

ДЕТЕРМИНАНТЫ ЖИЗНЕСТОЙКОСТИ У ТРЕХ ПОКОЛЕНИЙ СОВРЕМЕННОЙ РОССИИ

РосСИЙСКИй пСИХологИЧЕСКИй ЖУРнАл, 2020, Т. 17, № 1, 74-91. doi: 10.21702/rpj.2020.1.6

СОЦИАЛЬНАЯ ПСИХОЛОГИЯ

\section{Обсуждение результатов}

В ходе исследования было выявлено, что общий уровень жизнестойкости выше у представителей поколения Y, россиян в возрасте от 19 до 34 лет. Молодые респонденты уверены в своих решениях, им нравится быть постоянно занятыми, они предпочитают ставить перед собой труднодостижимые цели и добиваться их, им легко сближаться с новыми людьми, неожиданности дарят им интерес к жизни, а их собственная жизнь кажется им осмысленной и интересной. При выявлении детерминант жизнестойкости у трех поколений современной России было установлено, что на формирование жизнестойкости у всех трех поколений современной России оказывает влияние значимость смысложизненной ориентации «локус контроля - жизнь», тем не менее, у поколений X и Ү это влияние положительное, а у «беби-бумеров»- отрицательное. Также у поколения X и Y на формирование жизнестойкости оказывает влияние значимость ценностей индивидуализма - «самостоятельность: мысли» и «достижение». Кроме этого, на формирование жизнестойкости представителей поколения X, Y и «беби-бумеров» оказывает негативное влияние уровень экономической тревожности. Недовольство своим материальным положением и рост экономической тревожности снижают уровень жизнестойкости у всех трех поколений россиян. Рост материального благополучия может повысить уровень жизнестойкости у всех групп респондентов.

Проблема жизнестойкости человека и поиска факторов жизнестойкости у разных возрастных групп является крайне актуальной в современной науке на сегодняшний день, т. к. общество с его стремительными социально-экономическими изменениями, нестабильностью, потерей ценностных ориентиров становится все более стрессогенным. Жизнестойкость как единство установок на влияние, вызов и вовлеченность, обеспечивает мотивацию, необходимую для здоровьесберегающего поведения. В качестве детерминант жизнестойкости в представленной работе выступали индивидуальные ценности, смысложизненные ориентации и субъективное экономическое благополучие. Основная идея заключается в том, что умение справляться с жизненными трудностями и стрессогенными факторами зависит от личностного потенциала, ценностно-смысловых ориентиров и материального благополучия. Представители поколения Y (молодые россияне в возрасте от 18 до 34 лет) являются на данный момент наиболее жизнестойкими за счет доминирования у них факторов «вовлеченность» и «контроль». Значимость исследования состоит в расширении теоретических и эмпирических представлений об обусловленности жизнестойкости социально-психологическим контекстом и экономическими установками, а также в дальнейшем определении адаптационных возможностей представителей разных поколений на основе полученных данных.

\section{Благодарности}

Статья подготовлена в результате проведения исследования (№ 18-01-0046 «Взаимосвязь жизнестойкости с ценностно-смысловыми ориентациями и экономическими установками у представителей разных поколений россиян») в рамках Программы "Научный фонд Национального исследовательского университета "Высшая школа экономики" (НИУ ВШЭ)"» в 2018-2019 гг. и в рамках государственной поддержки ведущих университетов Российской Федерации «5-100». 
ФедОтова В. А.

ДЕТЕРМИНАНТЫ ЖИЗНЕСТОЙКОСТИ У ТРЕХ ПОКОЛЕНИЙ СОВРЕМЕННОЙ РОССИИ

Российский психологичЕский жУРнАл, 2020, Т. 17, № 1, 74-91. doi: 10.21702/rpj.2020.1.6

СОЦИАЛЬНАЯ ПСИХОЛОГИЯ

\section{Литература}

Арцимович, И. В. (2017). Современное поколение: вызовы обществу или времени? Интерактивная наука, 2(12), 119-121. doi: $10.21661 / r-117501$

Асташова, Ю. В. (2014). Теория поколений в маркетинге. Вестник ЮУрГу. Серия «Экономика и менеджмент», 8(1), 108-114.

Богомаз, С. А. и Баланев, Д. Ю. (2009). Жизнестойкость как компонент инновационного потенциала человека. Сибирский психологчческий журнал, 32, 23-28.

Ванакова, Г.В.(2014). Психологическая поддержка развития жизнестойкости студентов (кандидатская диссертация). Приамурский государственный университет им. ШоломАлейхема, Биробиджан.

Волкова, Н. В. и Чикер, В. А. (2016). Особенности карьерной мотивации в контексте теории поколений: Результаты эмпирического исследования. Вестник СПбГУ. Менеджмент, 4, 79-105. doi: 10.21638/11701/spbu08.2016.404

Гурова, И. М. и Евдокимова, С. Ш. (2016). Теория поколений как инструмент анализа, формирования и развития трудового потенциала. МИР (Модернизация. Инновации. Развитие), 7(3), 150-159. doi: 10.18184/2079-4665.2016.7.3.150.159

Кабанченко, Е. А. (2017). Феномен жизнестойкости в отечественных исследованиях. В Н. А. Лебедева (отв. ред.), Научный форум: Педагогика и психология: сб. cm. по материалам XIII междунар. науч.-практ. конф. (с. 103-106). Москва: Международный центр науки и образования.

Климов, А. А. (2010). Характеристика взаимосвязи структуры ценностных ориентаций и жизнестойкости у студентов. В В. А. Кузьмищев, О. А. Мазур, Т. Н. Рябченко, А. А. Шатохин (ред.), Молодежь и наука: реальность и будущее: Материалы III Международной научно-практической конференции в 6 m. T. 3 (с. 265-266). Невинномысск: Изд-во НИЭУП. Доступ 04 сентября 2019, источник https://pgu.ru/upload/iblock/cd7/vesternizaiya-_-novatsiya-iliindoktrinatsiya-s.504.pdf

Климов, А. А. (2011а). Взаимосвязь жизнестойкости и личностных ценностей студентов вуза. Молодые исследователи - регионам: материалы всероссийской научной конференции: в 2 m. T. 2 (с. 262-264). Вологда: ВоГТУ.

Климов, А. А. (20116). Жизнестойкость и ее взаимосвязь с личностными ценностями студентов. Вестник Самарской гуманитарной академии. Серия: Психология, 2(10), 14-23.

Кузьмина, Е. И. и Мороз, О. С. (2010). Свобода от фрустрации и жизнестойкость. Вестник Московского государственного областного университета. Серия: Психологические науки, 2, 5-8.

Леонтьев, Д. А. (2011). Новые ориентиры понимания личности в психологии: от необходимого к возможному. Вопросы психологии, 1, 3-27.

Леонтьев, Д. А. и Рассказова, Е. И. (2006). Тест жизнестойкости. Москва: Смысл.

Постникова, М.И. (2016). Особенности жизнестойкости молодежи. Научный диалог, 1(49), 298-310.

Хащенко, В. А. (2005). Социально-психологические детерминанты экономической идентичности личности. В А. Л. Журавлев, А. Б. Купрейченко (ред.), Проблемы экономической психологии (с. 513-556). М.: Институт психологии РАН.

Хащенко, В. А. (2011). Субъективное экономическое благополучие и его измерение: построение опросника и его валидизация. Экспериментальная психология, 4(1), 106-127.

Хомякова, Е. И. (2011). «Поколение Ү» в контексте социального взаимодействия в современном обществе. Известия Томского политехнического университета, 319(6), 153-156. 
ФедОтова В. А.

ДЕТЕРМИНАНТЫ ЖИЗНЕСТОЙКОСТИ У ТРЕХ ПОКОЛЕНИЙ СОВРЕМЕННОЙ РОССИИ

РосСИЙСКИй пСИХологИЧЕСКИй ЖУРнАл, 2020, Т. 17, № 1, 74-91. doi: 10.21702/rpj.2020.1.6

СОЦИАЛЬНАЯ ПСИХОЛОГИЯ

Хромов, А. Б. (2012). Атрибутивный стиль и субъективное благополучие представителей трех поколений россиян в эпоху культурной трансформации России. Вестник Курганского государственного университета. Серия: Физиология, психология и медицина, 23, 98-104.

Черников, Б. В. (2014). Дифференциация трудовых ценностей среди поколений современных работников. Вестник Томского государственного университета, 385, 153-158.

Шамис, Е. и Антипов, А. (н. д.). Теория поколений. Доступ 04 сентября 2019, источник https:// psycho.ru/library/2581

Шварц, Ш., Бутенко, Т. П., Седова, Д. С. и Липатова, А. С. (2012). Уточненная теория базовых индивидуальных ценностей: применение в России. Психология. Журнал Высшей школы экономики, 9(2), 43-70.

Anderson, H. J., Baur, J. E., Griffith, J. A., \& Buckley, M. R. (2017). What works for you may not work for (Gen)Me: Limitations of present leadership theories for the new generation. The Leadership Quarterly, 28(1), 245-260. doi: 10.1016/j.leaqua.2016.08.001

Haeberle, K., Herzber, J., \& Hobbs, T. (2009). Leading the multigenerational work force. A proactive approach will cultivate employee engagement and productivity. Healthcare Executive, 24(5), 62-67.

Kobasa, S. C., Maddi, S. R., \& Kahn, S. (1982). Hardiness and health: A prospective study. Journal of Personal and Social Psychology, 42(1), 168-177. doi: 10.1037/0022-3514.42.1.168

Macky, K., Gardner, D., \& Forsyth, S. (2008). Generational differences at work: Introduction and overview. Journal of Managerial Psychology, 23(8), 857-861. doi: 10.1108/02683940810904358

Mannheim, K. (1952). The problem of generations. In P. Kecskemeti (Ed.), Essays on the sociology of knowledge (pp. 276-320). London: Routledge and Kegan Paul.

Murphy, E. S., Gibson, J. W., \& Greenwood, R. A. (2010). Analyzing generational values among managers and non-managers for sustainable organizational effectiveness. SAM Advance Management Journal, 75(1), 33-55.

Ozkan, M., \& Solmaz, B. (2015). The changing face of the employees - generation Z and their perceptions of work (A study applied to university students). Procedia Economics and Finance, 26, 476-483. doi: 10.1016/S2212-5671(15)00876-X

Rudolph, C. W., Rauvola, R. S., \& Zacher, H. (2018). Leadership and generations at work: A critical review. The Leadership Quarterly, 29(1), 44-57. doi: 10.1016/j.leaqua.2017.09.004

Strauss, W., \& Howe, N. (1991). Generations: The History of America's Future, 1584 to 2069. New York: William Morrow.

Williams, K. C., Page, R. A., Petrosky, A. R., \& Hernandez, E. H. (2010). Multi-generational marketing: Descriptions, characteristics, lifestyles, and attitudes. Journal of Applied Business and Economics, 11(2), 115-132. Retrieved from: http://www.na-businesspress.com/JABE/Jabe112/WilliamsWeb.pdf

Wong, I. A., Wan, Y. K. P., \& Gao, J. H. (2017). How to attract and retain Generation Y employees? An exploration of career choice and the meaning of work. Tourism Management Perspectives, 23, 140-150. doi: 10.1016/j.tmp.2017.06.003

Yang, S.-B., \& Guy, M. E. (2006). Genxers versus Boomers: Work motivators and management implications. Public Performance \& Management Review, 29(3), 267-284. doi: 10.2753/PMR1530-9576290302

Yusoff, W. F. W., \& Kian, T. S. (2013). Generation differences in work motivation: From developing country perspective. International Journal of Economy, Management and Social Sciences, 2(4), 97-103.

Конфликт интересов отсутствует 